\title{
Emissions of $\mathrm{Fe}(\mathrm{II})$ and its kinetic of oxidation at Tagoro submarine volcano, El Hierro
}

\author{
Carolina Santana-González a , J. Magdalena Santana-Casiano ${ }^{\mathrm{a}, *}$, \\ Melchor González-Dávila ${ }^{\text {, }}$ Eugenio Fraile-Nuez ${ }^{\mathrm{b}}$ \\ a Instituto de Oceanografía y Cambio Global, IOCAG, Universidad de Las Palmas de Gran Canaria, Las Palmas de Gran Canaria, Spain \\ b Instituto Español de Oceanografía (IEO), Centro Oceanográfico de Canarias, Santa Cruz de Tenerife, Spain
}

\section{A R T I C L E I N F O}

\section{Article history:}

Received 11 October 2016

Received in revised form 22 December 2016

Accepted 1 February 2017

Available online xxxx

\section{Keywords:}

$\mathrm{Fe}(\mathrm{II})$

Oxidation

Acidification

Submarine volcano

\begin{abstract}
A B S T R A C T
The eruptive process that took place in October 2011 in the submarine volcano Tagoro off the Island of El Hierro and the subsequent degasification stage, five months later, have increased the concentration of TdFe(II) (Total dissolved iron(II)) in the waters nearest to the volcanic edifice. In order to detect any variation in concentrations of TdFe(II) due to hydrothermal emissions, three cruises were carried out two years after the eruptive process in October 2013, March 2014 and May 2015. The results from these cruises confirmed important positive anomalies in TdFe(II), which coincided with negatives anomalies in $\mathrm{pH}_{\mathrm{F}, \text { is }}$ ( $\mathrm{pH}$ in free scale, at in situ conditions) located in the proximity of the main cone. Maximum values in TdFe(II) both at the surface, associated to chlorophyll $a$ maximum, and at the sea bottom, were also observed, showing the important influence of organic complexation and particle re-suspension processes. Temporal variability studies were carried out over periods ranging from hours to days in the stations located over the main and two secondary cones in the volcanic edifice with positive anomalies in TdFe(II) concentrations and negative anomalies in $\mathrm{pH}_{\mathrm{F}, \text { is }}$ values. Observations showed an important variability in both $\mathrm{pH}_{\mathrm{F}, \text { is }}$ and $\mathrm{TdFe}$ (II) concentrations, which indicated the volcanic area was affected by a degasification process that remained in the volcano after the eruptive phase had ceased. Fe(II) oxidation kinetic studies were also undertaken in order to analyze the effects of the seawater properties in the proximities of the volcano on the oxidation rate constants and $\mathrm{t}_{1 / 2}$ (half-life time) of ferrous iron. The increased TdFe(II) concentrations and the low associated $\mathrm{pH}_{\mathrm{F}, \text { is }}$ values acted as an important fertilization event in the seawater around the Tagoro volcano at the Island of El Hierro providing optimal conditions for the regeneration of the area.
\end{abstract}

(c) 2017 Elsevier B.V. All rights reserved.

\section{Introduction}

Dissolved iron is the most bioavailable form assimilated by organisms (Brand, 1991; Hutchins et al., 1993). However, it is known that $\mathrm{Fe}(\mathrm{II})$ is thermodynamically unstable and is rapidly oxidized to $\mathrm{Fe}$ (III) in oxic waters (within seconds to minutes) (Kustka et al., 2005; Millero and Izaguirre, 1989; Santana-Casiano et al., 2005). Fe(III) has a very low solubility (Liu and Millero, 2002). The concentration of $\mathrm{TdFe}(\mathrm{II})$ dissolved in shallow and deep waters depends on the rate of oxidation of $\mathrm{Fe}(\mathrm{II})$ which is a function of both the $\mathrm{O}_{2}$ and $\mathrm{H}_{2} \mathrm{O}_{2}$ concentration, $\mathrm{pH}$, temperature, $\left[\mathrm{HCO}_{3}^{-}\right]$, ionic strength and nutrient concentration (González-Davila et al., 2005; González-Dávila et al., 2006; González et al., 2010; King and Farlow, 2000; Miller et al., 1995; Santana-Casiano et al., 2005; Shi et al., 2010). For this reason, the concentrations of dissolved Fe(II) in the open ocean are very low, with typical values in the 0.02 to $2 \mathrm{nmol} \mathrm{L}^{-1}$ ranges. However, typical

\footnotetext{
* Corresponding author.

E-mail address: magdalena.santana@ulpgc.es (J.M. Santana-Casiano).
}

concentrations of dissolved iron in hydrothermal vents are 1$3 \mathrm{mmol} \mathrm{L}^{-1}$, with extreme values of about $18.7 \mathrm{mmol} \mathrm{L}^{-1}$ measured in the Juan de Fuca Ridge (de Baar and de Jong, 2001). In these areas, $\mathrm{Fe}(\mathrm{II})$ remains in solution over longer time periods due to $\mathrm{pH}$ and $\mathrm{p} \varepsilon$ (reduction potential) conditions.

Hydrothermal vents require hydrothermal fluid circulation during tectonic or magmatic and volcanic activity, which provides fluid pathways in the fractured oceanic crust and heat sources (Mantas et al., 2011). The composition of the hydrothermal fluid, which migrates to the subsurface and finally discharges at the sea floor, depends on a number of critical parameters including temperature, pressure, phase separation and host rock composition (Sander and Koschinsky, 2011). Hydrothermal emissions of gases and particles are an important source of material of different size, texture and chemical composition, such as gases and metals, especially reduced iron (Santana-Casiano et al., 2013).

The hydrothermal vents affect the chemical composition of seawater (Resing et al., 2015; Tagliabue et al., 2010) and their diffuse fluxes regulate the magnitude of dissolved Fe in the plume to the deep ocean (Resing et al., 2015; Tagliabue et al., 2010; German et al., 2015). These 
vents could provide from 9\% (Sander and Koschinsky, 2011) to 12-22\% of the global deep-ocean dissolved Fe budget (Bennett et al., 2008). However, geographic variability in the production of $\mathrm{Fe}(\mathrm{III})$ particles in hydrothermal plumes is more dependent on chemical conditions in the ambient deep water than on compositional variations in the primary vent fluid. These variations may cause $\mathrm{Fe}$ (II) oxidation rates (Field and Sherrell, 2000) and residence time scales to vary greatly among the ocean basins which receive hydrothermal input (Nishioka et al., 2013). After the hydrothermal emission, $\mathrm{Fe}(\mathrm{II})$ is oxidized under the presence of dissolved oxygen and precipitates into various mineral forms, mainly oxy-hydroxide (de Baar and de Jong, 2001) forming massive deposits of iron, but around $4 \%$ of the total emitted iron is stabilized against loss from solution due to complexation by dissolved organic ligands (Bennett et al., 2008; Resing et al., 2015), or by incorporation into inorganic or organic colloids which reside within the dissolved size fraction (Resing et al., 2015). Moreover, reduced species of Fe and $\mathrm{S}$ form an FeS colloidal complex, which remains suspended in the water and is modified as the pH changes (Luther et al., 2001). These nanoparticles can remain suspended in the deep sea for years with slower settling rates (Yücel et al., 2011), solubilizing and releasing the $\mathrm{Fe}(\mathrm{II})$. The complexation significantly increases metal content from hydrothermal systems, increasing trace-metal flux to the global ocean. The largest and most widespread Fe anomalies have been found in the Pacific, the Indian and the Atlantic basins (Tagliabue et al., 2010).

In 2011, Tagoro submarine volcano was formed $1.8 \mathrm{~km}$ south of the Island of El Hierro, the westernmost island of the Canary Archipelago. During the eruptive stage that was initiated on October 10 of 2011 and finished in March 2012, large amounts of gases and reduced chemical species were emitted (Fraile-Nuez et al., 2012). During these five first months, the carbonate system in the seawater was strongly affected and the pH decreased to 5.1 due to $\mathrm{CO}_{2}$ emissions. $\mathrm{Fe}(\mathrm{II})$ and reduced sulfur concentrations increased to $50 \mu \mathrm{mol} \mathrm{L}^{-1}$ and $200 \mu \mathrm{mol} \mathrm{L}{ }^{-1}$, respectively. The reaction between the reduced species of Fe(II) and $\mathrm{S}$ also contributed to the acidification of the system (Eq. 1) and the FeS formed contributed to stabilizing the Fe(II) (Santana-Casiano et al., 2013).

$\mathrm{Fe}(\mathrm{II})+\mathrm{H}_{2} \mathrm{~S} \leftrightarrow \mathrm{FeS}+2 \mathrm{H}^{+}$

Just after the molten eruptive phase, changes in the characteristics of the gas and reduced species emissions also modified the carbonate system and decreased both $\mathrm{p} \varepsilon$ and $\mathrm{pH}$, which favor the presence of $\mathrm{Fe}(\mathrm{II})$. Emissions of $\mathrm{CO}_{2}$ gas and carbonate alkalinity from the El Hierro submarine volcano accounted for $60 \%$ and $40 \%$, respectively, of the $\mathrm{pH}$ change in local seawater (Santana-Casiano et al., 2016).

This work focuses on the study of the variation in the concentration of total dissolved $\mathrm{Fe}(\mathrm{II})$ and $\mathrm{pH}_{\mathrm{F} \text {,is }}$ in the seawater column due to hydrothermal emissions from the shallow submarine Tagoro volcano. The presence of shallow hydrothermal vents close to the coastal area in the post-eruptive phase of the submarine volcano (Santana-Casiano et al., 2016) provided the opportunity to study the emission of total dissolved $\mathrm{Fe}(\mathrm{II})$, the changes in the $\mathrm{pH}$ of the surrounding waters and the correlation of those changes with the TdFe(II) concentration. The results obtained generated information about both the oxidation kinetics of $\mathrm{Fe}(\mathrm{II})$ and the effects of the natural $\mathrm{Fe}(\mathrm{II})$ fertilization process taking place in the area.

\section{Material and methods}

\subsection{Study location}

The study was conducted in the region of the Tagoro submarine volcano, south of the island of El Hierro (Canary Islands, Spain, at $27^{\circ} 37^{\prime} 07^{\prime \prime}$ $\mathrm{N}-017^{\circ} 59^{\prime} 28^{\prime \prime} \mathrm{W}$, Fig. 1A), during the oceanographic cruises of VULCANO in October 2013 and March 2014 and VULCANA in May 2015 on board the R/V Ángeles Alvariño. A grid of CTD stations around the El Hierro Island (Fig. 1B) and a high-resolution CTD study along the main cone of the volcano edifice (Fig. 1C) were carried out, with samples taken at different depths. A map of active hydrothermal vents location has been published (Santana-Casiano et al., 2016) generated following both $\mathrm{pH}$ and ORP (oxidation-reduction potential) anomalies in the Tagoro volcano.

\subsection{Reagents}

\subsubsection{Iron stock}

An iron stock of $6.21 \times 10^{-4} \mathrm{~mol} \mathrm{~L}^{-1}$ was prepared using ammonium iron(II) sulfate hexahydrate (SIGMA-ALDRICH). $\mathrm{HCl}$ (HIPERPURPLUS, previously quartz distilled, $\mathrm{Q}-\mathrm{HCl}$ ) was added to the water to lower the $\mathrm{pH}$ to 2 and retard any oxidation. It was then stored in the dark until use. A diluted stock was prepared daily with a final concentration of $2.42 \times 10^{-6} \mathrm{~mol} \mathrm{~L}^{-1}$.

\subsubsection{Luminol}

The luminol was prepared using $0.2487 \mathrm{~g}$ of 5-amino-2,3-dihydro1,4-phthalazinedione (FLUKA), $26.4976 \mathrm{~g}$ of $\mathrm{Na}_{2} \mathrm{CO}_{3}$ (SIGMA-ALDRICH) and $188.175 \mathrm{~mL}$ of $\mathrm{NH}_{3}$ (PANREAC) (HIPERPUR-PLUS, previously distilled) in a total volume of $5 \mathrm{~L}$ of luminol reagent. The final $\mathrm{pH}$ was adjusted to 10.4 by adding $6 \mathrm{M} \mathrm{Q}-\mathrm{HCl}$. At this $\mathrm{pH}$, luminescence is optimal (Bowie et al., 1998). The luminol solution was stored in the dark due to its light sensitivity. To ensure complete dilution, it was prepared a few days prior to use. The solution became more stable $24 \mathrm{~h}$ after preparation and for at least a month after (King et al., 1995).

\subsubsection{Carrier}

The carrier used was $0.7 \mathrm{M} \mathrm{NaCl}$, to achieve an ionic strength similar to that of seawater in standards and samples. All the reagents were prepared with deionized ultrapure water (Milli-Q, $18.2 \mathrm{M} \Omega . \mathrm{cm}^{-1}$, Millipore). Milli-Q water was used as a cleaner between injections.

\subsection{Sampling}

$\mathrm{TdFe}(\mathrm{II})$ and $\mathrm{pH}$ samples in the water column were collected using $10 \mathrm{~L}$ Niskin bottles mounted on a 24 position rosette frame fitted with a SeaBird SBE11 Plus CTD and with a SBE18 pH sensor. Acid pre-cleaned $50 \mathrm{~mL}$ polyethylene containers were used and fitted with $45 \mathrm{~mL}$ of unfiltered sample. Prior to sampling, $10 \mu \mathrm{L}$ of $\mathrm{Q}-\mathrm{HCl}(6 \mathrm{M})$ was added to the containers in order to keep the seawater solution at $\mathrm{pH} 6$. The samples were stored in the refrigerator at $4{ }^{\circ} \mathrm{C}$ until analysis to reduce the rate of $\mathrm{Fe}(\mathrm{II})$ oxidation. All the samples were always analyzed in a period of time lower than $3 \mathrm{~h}$ and no statistically significant differences were observed with samples that were analyzed immediately. The same methodology was followed for all the samples in this study. An intercomparison exercise was done at the initial stages of the cruise at four stations (50, 54, 59 and 61) where Go-Flo bottles with Kevlar cable and the Niskin bottles in the CTD rosette were used at the same depth (16 m) (Supplementary material, Table 1 ). Samples were also taken at $1 \mathrm{~m}$ from the bottom with the Go-Flo bottles. All the samples were transferred to a clean room on the ship for sampling and analysis.

Before use, all the material was rinsed three times with distilled water, three times with Milli-Q water and stored in $10 \% \mathrm{HCl}$ solution for cleaning. When the material was going to be used, it was rinsed three times with distilled water and three times with Milli-Q water. After the analysis, the material was cleaned and re-stored in the $\mathrm{HCl}$ solution.

\subsection{Measurements}

\subsubsection{Fe (II) concentration}

All the samples were analyzed on board. Before injection into the system, the samples were tempered at $20{ }^{\circ} \mathrm{C}$. In order to determine the concentration of $\mathrm{TdFe}(\mathrm{II})$ in seawater the FeLume system 

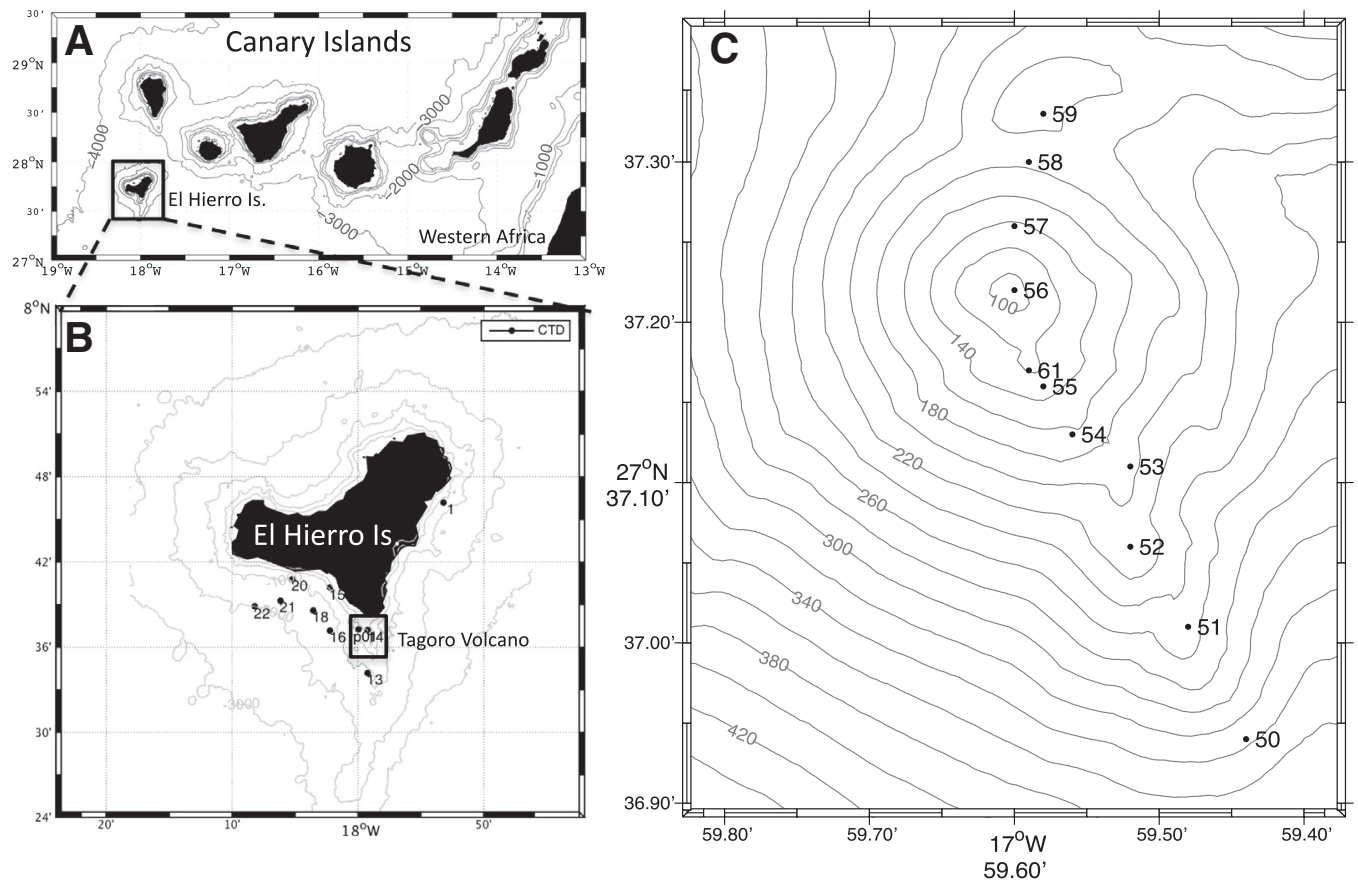

Fig. 1. A) General map of the Canary Archipelago. B) Island of El Hierro and reference stations sampled. C) Stations sampled in the high-resolution study.

(Waterville Analytical) was selected. The FIA-chemiluminescence technique uses luminol as the reagent (King et al., 1995). Dissolved, colloidal and labile phases of $\mathrm{Fe}(\mathrm{II})$ are determined and expressed as TdFe(II).

In the FIA system, four hoses are used and placed in a peristaltic pump (Rainin Dynamax 15.8 V), which connects them to the mixing chamber and to the detector. Subsequently, the pressure is regulated in the hoses while Milli-Q water passes through it. This allows the flow to be uniform and not in pulses. After adjusting the pressure in the hoses, the watercleaning mode was enabled during $3 \mathrm{~min}$. After this time, air was allowed to pass and then each hose was introduced into the corresponding receptacles: luminol, $\mathrm{NaCl}$, Milli-Q water and sample. The software executed in the FeLume-chemiluminescence was provided by Waterville analytical (WA control V105, photo counter control). An analysis time of $100 \mathrm{~s}$ was selected, to allow full recording of the peak signal. The peak area mode was selected in order to compute the signal. Three measurements for each sample were carried out and values were presented as average values. After a set of analyses, Milli-Q water was used to clean all hoses, and finally air was run to empty them.

\subsubsection{Standards and calibration procedure}

Seawater used in the calibration procedure of the chemiluminescence signal was taken from a station unaffected by the volcano and aerated with a magnetic stirrer during $60 \mathrm{~min}$ in atmospheric contact. The solution was stirred at maximum speed for $1 \mathrm{~h}$ to oxygenate the sample at the selected temperature and $\mathrm{pH}$. This time was sufficient to achieve complete oxidation of Fe(II) (Hansard and Landing, 2009; Santana-Casiano et al., 2004), and the matrix of the sample was maintained following the procedure carried out by Hansard and Landing (2009).

$25 \mathrm{~mL}$ flasks, into which $10 \mu \mathrm{L}$ of $6 \mathrm{~mol} \mathrm{~L}^{-1} \mathrm{Q}-\mathrm{HCl}$ was added, were used in the standardization process. The required diluted iron stock was added to reach the final concentration and the flask was filled with seawater. The final $\mathrm{pH}$ in the flask was 6 . A control with no addition of iron was prepared at each calibration step. Every day, three standards were performed to ensure that the initial calibration was maintained and small changes in the sensitivity were corrected. The calibration curves used were made in the concentration range 0.9 to $7.7 \mathrm{nmol} \mathrm{L}^{-1}$ with correlation coefficients of $\mathrm{r}^{2}=0.999$. The detection limit obtained was
$0.09 \mathrm{nM}(\mathrm{LD}=3 \mathrm{xSTD}[\overline{\text { Blank }}], \mathrm{n}=4)$ and the quantification limit was $0.3 \mathrm{nM}(\mathrm{LQ}=10 \mathrm{xSTD}[\overline{\text { Blank }}], \mathrm{n}=4)$.

\subsection{3. $\mathrm{pH}$}

$\mathrm{pH}$ was measured in the whole water column using an SBE18 $\mathrm{pH}$ sensor that provides the values expressed in an NBS (National Bureau of Standards) scale. It uses a pressure-balanced glass-electrode Ag/ $\mathrm{AgCl}$-reference $\mathrm{pH}$ probe to provide in situ measurements at depths of up to $1200 \mathrm{~m}$. The $\mathrm{pH}$ sensor was calibrated against precision buffer solutions of 4,7 , and 10 with $\pm 0.02 \mathrm{pH}$ units standard deviation.

Discrete samples were measured on the total scale at a constant temperature of $25{ }^{\circ} \mathrm{C}\left(\mathrm{pH}_{\mathrm{T}, 25}\right)$ by the UV-Vis spectrophotometric technique (Clayton and Byrne, 1993), using m-cresol purple as indicator (González-Dávila et al., 2003). The standard deviation for the measurements was \pm 0.002 and the accuracy of the system was 0.002 .

In order to homogenize all $\mathrm{pH}_{\mathrm{NBS}}$ values provided by the sensor and to convert them to $\mathrm{pH}$ in total scale at in situ conditions, $\mathrm{pH}_{\mathrm{T}, \mathrm{is}}$, a correlation equation was obtained. First, the measured $\mathrm{pH}_{\mathrm{T}, 25}$ values were converted to in situ conditions using dissolved inorganic carbon data (data not shown) and the $\mathrm{CO}_{2}$ Sys program (Lewis et al., 1998; Santana-Casiano and González-Dávila, 2011). Then, the converted pH values were correlated with those measured with the sensor. Due to changes in the $\mathrm{pH}$ sensor reading with deployments, the equation changed for each of them.

In the kinetic experiments, $\mathrm{pH}$ was measured on the free scale and Tris buffer was used (Millero, 1986). All the pH data in the text and in the figures, including kinetic and profile data are expressed in free scale.

\subsubsection{ORP}

The ORP sensor has a platinum working electrode and an $\mathrm{Ag} / \mathrm{AgCl}$ reference electrode located in a single PEEK thermoplastic body. The sensor range was -500 to $+500 \mathrm{mV}$, with output scaled to $0-5 \mathrm{~V}$ for an auxiliary analog channel on the CTD. The ORP sensor does not provide an absolute electric potential, however, the sensors respond instantaneously to the presence of reduced chemical species with a decrease in the measured potential. ORP data were expressed as a time derivative 

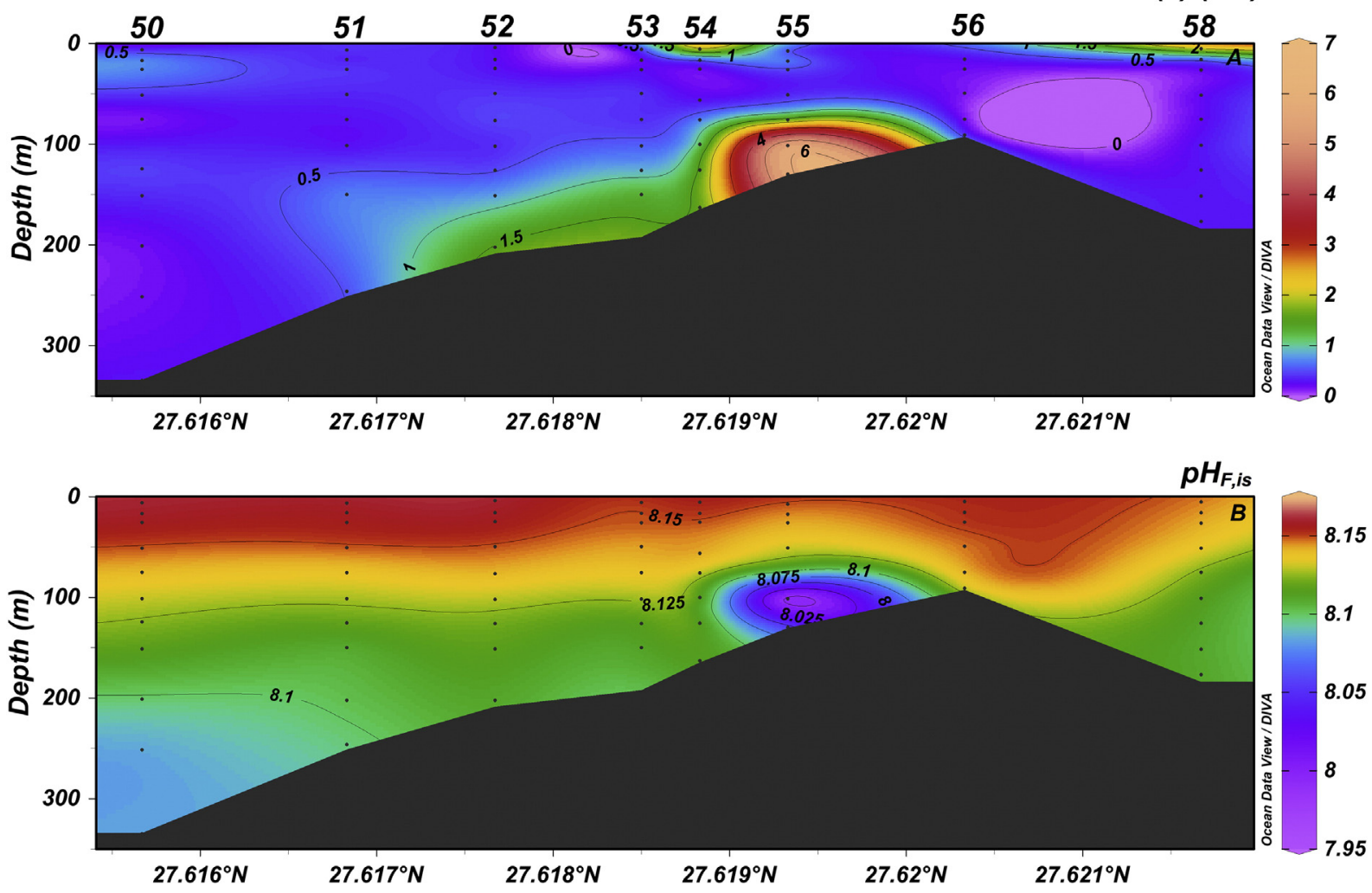

Fig. 2. A) $\mathrm{TdFe}(\mathrm{II})$ and $\mathrm{B}$ ) $\mathrm{pH}_{\mathrm{F}, \text { is }}$ vertical distributions in the high-resolution study along the volcano transect in November 2013 .

(dorp/dz), and anomalies were identified by negative values (SantanaCasiano et al., 2016).

\subsubsection{Kinetic studies}

The kinetic studies were carried out in a thermo-regulated cell connected to a thermostatic bath (PolyScience). For each study, the seawater was tempered to the chosen temperature. When the temperature was stable, the $\mathrm{pH}$ for the sample and for the Tris buffer was measured.

For the kinetics studies, $75 \mathrm{~mL}$ of seawater samples from two different depths were used ( $341 \mathrm{~m}$ at station 50 and $5 \mathrm{~m}$ at tow-yo site_04). The initial concentration of added TdFe(II) was $4 \mathrm{nM}$. Fe(II) concentrations of $16 \mathrm{nM}$ and $9.6 \mathrm{nM}$ were also used for those kinetic studies where the oxidation rate was quick and the $t_{1 / 2}$ was lower than $1.7 \mathrm{~min}$. All studies were done in the dark.

For each kinetic study, the seawater was placed in the glass cell and the magnetic stirrer was switched on for $1 \mathrm{~h}$ to attain the equilibrium oxygen concentration. When the solution was tempered and the $\mathrm{pH}$ stable at the desired value, the sample hose was introduced into the cell. After that, the iron stock was added and the stopwatch was started simultaneously at time $0 \mathrm{~s}$.

The rates of oxidation of $\mathrm{Fe}(\mathrm{II})$ (Santana-Casiano et al., 2005) were expressed as an apparent oxidation rate, $k_{\mathrm{app}}\left(\mathrm{M}^{-1} \mathrm{~min}^{-1}\right)$

$\frac{d[\mathrm{Fe}(I I)]}{d t}=-k_{\text {app }}[\mathrm{Fe}(\mathrm{II})]\left[\mathrm{O}_{2}\right]$

The brackets denote the total molar concentration. The oxygen concentration was calculated using the Benson and Krause (1984) equation. In aerate solutions, the $\mathrm{Fe}(\mathrm{II})$ kinetic studies followed a pseudofirst-order, $k^{\prime}\left(\min ^{-1}\right)$

$\frac{d[\mathrm{Fe}(I I)]}{d t}=-k^{\prime}[\mathrm{Fe}(I I)]$

where $k^{\prime}=k_{\text {app }}\left[\mathrm{O}_{2}\right]$

\section{Results}

A high spatial resolution CTD study following the alignment of the main and secondary cones of the submarine volcano and several CTD yo-yo studies, at the stations close to the main cone, were carried out in all the cruises (Santana-Casiano et al., 2016). The changes in temperature and salinity due to the effect of the emissions as the CTD approached the active vents were not appreciable in this shallow-low temperature hydrothermal system. For that reason, chemical sensors were used. The variables measured for each station (temperature, salinity, $\mathrm{pH}, \mathrm{TdFe}(\mathrm{II})$ and dorp/dz) have been included in the Supplementary Table 2.

During the yo-yo studies, bottle samples were taken only when extreme anomalies were observed in the $\mathrm{pH}$ and/or ORP sensors in the downward CTD-rosette scanning. Nine hydrographical CTD stations around the whole island were used as reference stations $(13,14,15,16$, 18, 20, 21, 22 and p_01) (Fig. 1B). $\mathrm{pH}_{\mathrm{F}, \text { is }}$ and TdFe(II) concentrations were analyzed in all the stations in order to quantify both the contribution of the hydrothermal vent to the pool of TdFe(II) and to determine whether the emission continued with time. Beyond the influence of the volcano, in the reference stations, typical vertical profiles of $\mathrm{TdFe}(\mathrm{II})$ and $\mathrm{pH}_{\mathrm{F} \text {,is }}$ were obtained. For the reference stations, TdFe(II) values below $0.1 \mathrm{nM}$ were characteristic and the $\mathrm{pH}_{\mathrm{F}, \text { is }}$ changed from 8.10 in the surface water to 8.03 at $200 \mathrm{~m}$ depths. No significant differences were observed between TdFe(II) samples from Go-Flo and Niskin bottles in the selected stations where both bottles were used (Supplementary Table 1).

The vertical distribution of TdFe(II) concentration along the highresolution section across the volcano is shown in Fig. 2A. The sea surface waters presented low $\mathrm{TdFe}(\mathrm{II})$, with values of around $0.2 \mathrm{nM}$, except in stations 54 and 58 where concentrations of TdFe(II) reached 2.72 and $2.32 \mathrm{nM}$, respectively. Most of the stations, including the reference stations, showed a slight increase in iron concentration at $25 \mathrm{~m}$, associated to the maximum of chlorophyll $a$ in the section (not shown), with values from 0.2 to $0.9 \mathrm{nM}$. Moreover, all the stations sampled over the high resolution study presented an important increase in $\mathrm{TdFe}(\mathrm{II})$ 
from $50 \mathrm{~m}$ to the lowest measurable depth, with the exception of the southernmost and deepest station (50), which showed only a small increase of $0.2 \mathrm{nM}$. Values between 1.5 and $1.8 \mathrm{nM}$ were measured at the bottom (160-200 $\mathrm{m}$ ) for stations 52,53 and 54 . The maximum anomaly in TdFe(II), $7.34 \mathrm{nM}$, was measured at $100 \mathrm{~m}$ in station 55, the station closest to the top of the volcano.

The vertical distribution of $\mathrm{pH}_{\mathrm{F}, \mathrm{is}}$ at in situ conditions in the high-resolution study along the volcano is shown in Fig. 2B. At the sea surface, $\mathrm{pH}_{\mathrm{F}, \text { is }}$ was 8.160, except in stations 55,56 and 58 , which had values of $8.149,8.152$ and 8.145 , respectively. All the stations presented a decrease in $\mathrm{pH}_{\mathrm{F}, \text { is }}$ values from $50 \mathrm{~m}$ to the bottom. However, values were 0.01 to 0.02 units lower than those observed at station 50. Minimum $\mathrm{pH}_{\mathrm{F} \text {,is }}$ values were recorded at station 55 , with a $\mathrm{pH}$ of 7.96 at $100 \mathrm{~m}$, 0.17 units lower than for station 50 . This $\mathrm{pH}$ value increased as we moved away from station 55 .

As can be observed in Fig. $2 \mathrm{~A}$ and B, an important anomaly was observed in station 55 for both $\mathrm{TdFe}(\mathrm{II})$ and $\mathrm{pH}_{\mathrm{F}, \mathrm{is}}$. In order to verify this anomaly, station 55 was measured 106 times from the surface to $1 \mathrm{~m}$ above the seabed during eight yo-yo CTD studies with 22, 45, 6, 9, 12 , 5,4 and 3 CTD casts, respectively. TdFe(II) was sampled at selected depths during casts 01,68 and 83 on November 3 (13:00), 5 (21:00) and 7 (18:00), respectively. The TdFe(II) vertical profiles for stations 55, 55-68 and 55-83, are plotted in Fig. 3A. In all the studies, an important iron anomaly was observed at the same depth of $100 \mathrm{~m}$. This anomaly reached values as high as $7.34 \mathrm{nM}, 1.4 \mathrm{nM}$ and $48.92 \mathrm{nM}$ on

\section{$[\mathrm{Fe}(\mathrm{II})] \mathrm{nM}$}
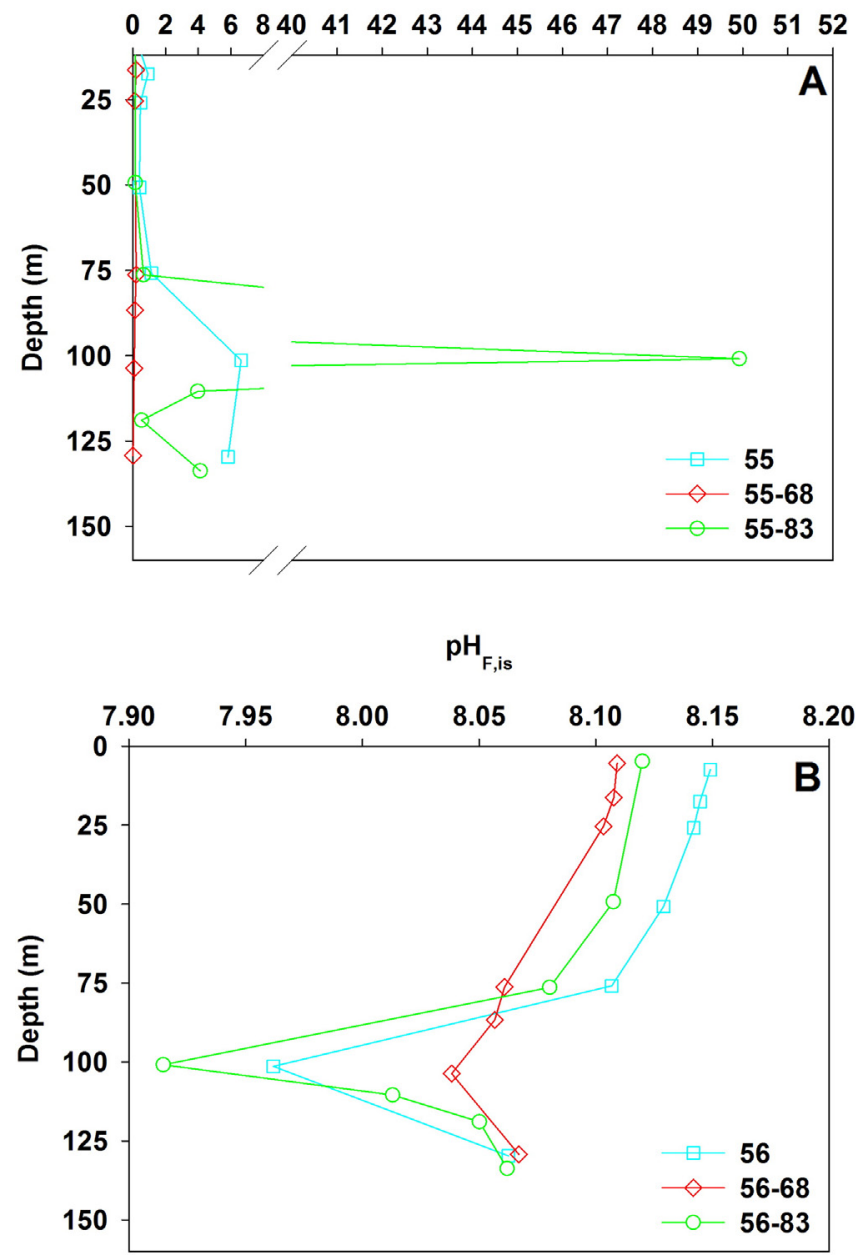

Fig. 3. A) $\mathrm{TdFe}(\mathrm{II})$ and $\mathrm{B}$ ) $\mathrm{pH}_{\mathrm{F}, \text { is }}$ at station 55 on three different days during the same cruise. The stations 55, 55-68 and 55-83 were sampled on November 2013, 3, 5 and 7, respectively.
November 3, 5 and 7, respectively. As can be seen in Fig. 3B, the vertical profiles of $\mathrm{pH}_{\mathrm{F}, \text { is }}$ for stations 55, 55-68 and 55-83 also show important $\mathrm{pH}_{\mathrm{F}, \text { is }}$ anomalies. Surface values ranged between 8.14 and 8.11 , while at $100 \mathrm{~m}$ depths an important anomalous decrease in $\mathrm{pH}_{\mathrm{F}, \text { is }}$ was observed, reaching values of 7.96, 8.03 and 7.91 on November 3, 5 and 7, respectively.

In March 2014, a similar study was repeated and TdFe(II) and $\mathrm{pH}_{\mathrm{F}, \text { is }}$ were sampled along the high-resolution section. The sea surface waters presented TdFe(II) concentrations with values ranging between 0.1 and $1 \mathrm{nM}$. Similarly to the previous study, a slight enhanced iron concentration was observed at $25 \mathrm{~m}$ for some stations, associated to the maximum in chlorophyll $a$, and all the stations presented a slight increase of $\mathrm{Fe}$ (II) from $100 \mathrm{~m}$ to the bottom, with the highest anomaly values recorded at station 56, in the main crater, close to station 55 . The $\mathrm{pH}_{\mathrm{F} \text {,is }}$ at in situ conditions also presented the highest values in the surface waters, 8.20 , as in the previous studies, but in this case, 0.05 units higher than in November 2013, due to the seasonal variability of pH in the Canary region (Santana-Casiano and González-Dávila, 2011). All the stations presented a decrease in $\mathrm{pH}_{\mathrm{F}, \text { is }}$ from $50 \mathrm{~m}$ to the bottom. However, minimum $\mathrm{pH}_{\mathrm{F} \text {,is }}$ values were measured at station 56 , along the whole profile, with a $\mathrm{pH}_{\mathrm{F} \text {,is }}$ value of 8.16 at the bottom.

During the March 2014 cruise, 7 tow-yos were done in an area chosen specifically to more precisely determine the extent of the $\mathrm{pH}_{\mathrm{F}}$,is anomalies around the volcanic edifice (Santana-Casiano et al., 2016). On this occasion, two stations were selected to carry out the yo-yo CTD studies, stations 56 and 61. Fig. 4A and B show the anomalies in the vertical profile of $\mathrm{TdFe}(\mathrm{II})$ at stations 56 and 61. In station 56 this anomaly was located at all depths, especially at $90 \mathrm{~m}$. The values were $0.13 \mathrm{nM}$ and $2.04 \mathrm{nM}$ at surface waters and $0.74 \mathrm{nM}$ and $3.52 \mathrm{nM}$ at $90 \mathrm{~m}$, in stations 56 and 56-03, respectively. The time difference between the two samplings was five days. In station 61 , the anomaly was more intense and located at around $120 \mathrm{~m}$. The values of TdFe(II) in the bottom water were $1278.9 \mathrm{nM}$ and $281 \mathrm{nM}$ in stations 61-42 and 61-61, respectively. These stations were sampled within only four and a half hours of each other. $\mathrm{pH}_{\mathrm{F}, \text { is }}$ anomalies were also observed in stations 56 and 61, at the same depths (Fig. 4C and D). Changes of $\mathrm{pH}_{\mathrm{F}, \text { is }}$ between stations 56 and 56-03 were 0.01 in surface waters and 0.02 at $90 \mathrm{~m}$, with a time difference of five days between the two samplings. The anomaly was observed all along the water column. In station 61 , the anomaly was much more intense in the deeper waters, with changes of 0.08 units between casts.

One year later (Fig. 5A), the study was repeated and a similar pattern to that of the previous two cruises was found. Stations 56 and 58 presented TdFe(II) surface values that reached 3.06 and $3.24 \mathrm{nM}$, respectively. An enhanced iron concentration was observed at $25 \mathrm{~m}$ for almost all stations and a sharp increase in $\mathrm{TdFe}$ (II) was located at $97 \mathrm{~m}$ in station 56 with a value of $44.61 \mathrm{nM}$. With respect to the $\mathrm{pH}_{\mathrm{F}, \mathrm{is}}$, (Fig. 5B), an important decrease to 8.00 was observed in station 56 , representing a change of 0.15 units for this station. Sampling at station 56 was repeated two hours later and values of TdFe(II) of $5.53 \mathrm{nM}$ and $\mathrm{pH}_{\mathrm{F} \text {,is }}$ of 8.08 were obtained at the same depth.

Fig. $6 \mathrm{~A}$ shows the concentrations of TdFe(II) at the bottom depth between $343 \mathrm{~m}$ (station 50) and $88 \mathrm{~m}$ (station 56), following the volcano shape. Two iron anomalies were detected during the October 2013 cruise: the first one between stations 52 and 53, where values of $1.59 \mathrm{nM}$ and $1.77 \mathrm{nM}$ were obtained, respectively, and the second at station 55, where a concentration of $6.44 \mathrm{nM}$ was obtained. During the March 2014 cruise, two iron anomalies were again observed: the first one between stations 53-02 and 54, with values of $2.96 \mathrm{nM}$ and $1.33 \mathrm{nM}$, respectively, and the second one at station 57 , where a concentration of $2.06 \mathrm{nM}$ was obtained. During May 2015, a very strong signal was located at station 56 of $44.61 \mathrm{nM}$ and two weak signals were located at stations 52 and 58 with values of 4.16 and 3.80, respectively. Fig. $6 \mathrm{~B}$ shows the results for $\mathrm{pH}_{\mathrm{F}, \mathrm{s} \text {. }}$ A trend opposite to that showed by the TdFe(II) (Fig. 6A) was observed. In the October 2013 cruise, a low $\mathrm{pH}_{\mathrm{F} \text {, is }}$ value was observed at station 55 (8.06), the lowest for the section. 
[Fe(II)] nM

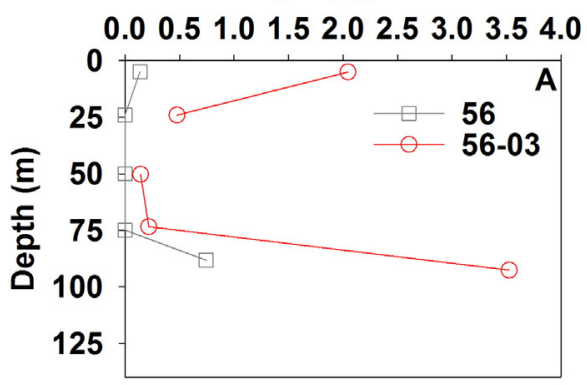

$\mathbf{p H}_{\mathbf{F}, \text { is }}$

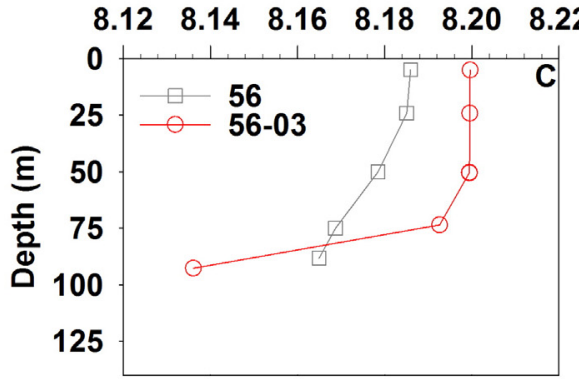

$[\mathrm{Fe}(\mathrm{II})] \mathrm{nM}$

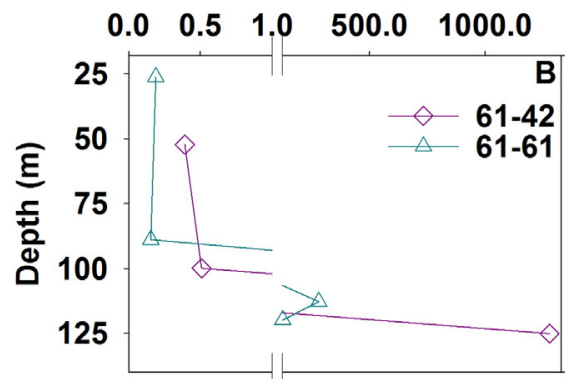

$\mathrm{pH}_{\mathrm{F} \text {,is }}$

$7.76 \quad 7.84 \quad 7.92 \quad 8.00 \quad 8.08 \quad 8.16$

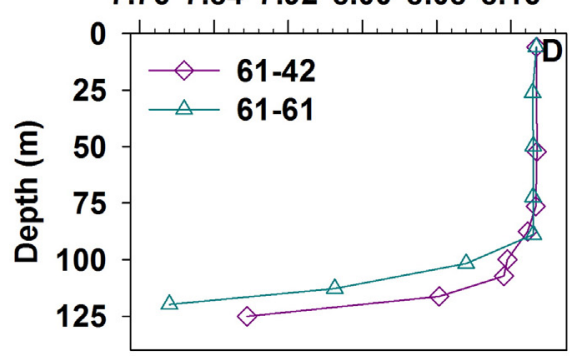

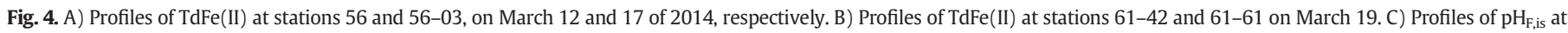
stations 56 and 56-03 on March 12 and 17, respectively. D) Profiles of $\mathrm{pH}_{\mathrm{F}, \text { is }}$ at stations 61-42 and 61-61 on March 19.

Moreover, a slight decrease in $\mathrm{pH}_{\mathrm{F}, \text { is }}$ was also measured in station 53 (value of 8.10, lower than those at the adjacent stations) and at stations 50,51 and 58 which had values of $8.08,8.09$ and 8.10, respectively. However, in the March 2014 cruise, low $\mathrm{pH}_{\mathrm{F}, \text { is }}$ values were observed at stations 56 and 57 ( 8.16 and 8.13, respectively), and at station 54 , with a value of 8.13. During the May 2015 cruise, a strong decrease in $\mathrm{pH}_{\mathrm{F}, \mathrm{is}}$ was found in station 56 , with a value of 8.00 . This value represents 0.13 and 0.16 units less than the corresponding values at the same
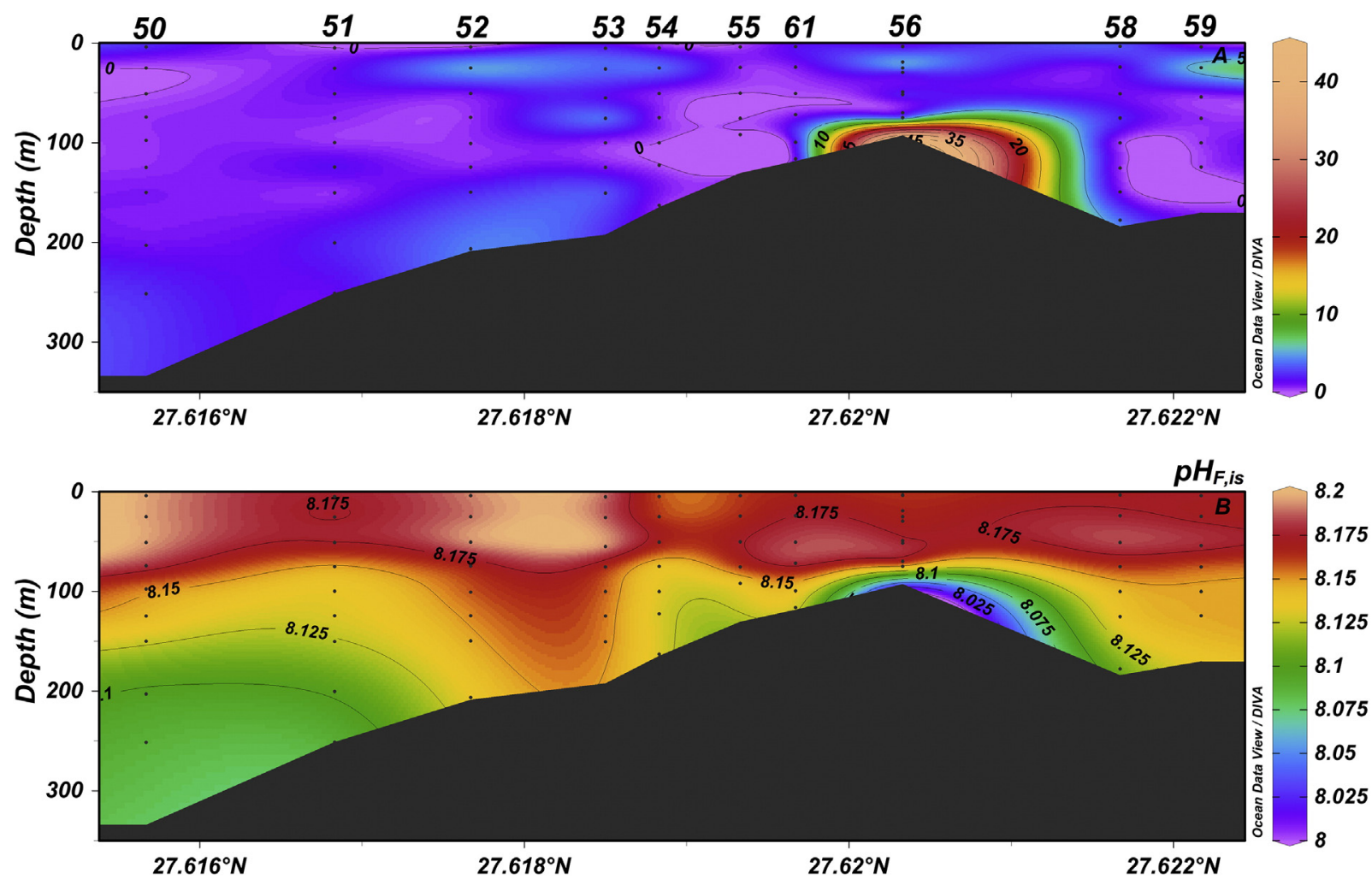

Fig. 5. Vertical distributions of $\mathrm{A}$ ) $\mathrm{TdFe}(\mathrm{II})$ and $\mathrm{B}$ ) $\mathrm{pH}_{\mathrm{F}, \text { is }}$ in the high resolution study along the volcano transect in May 2015. 

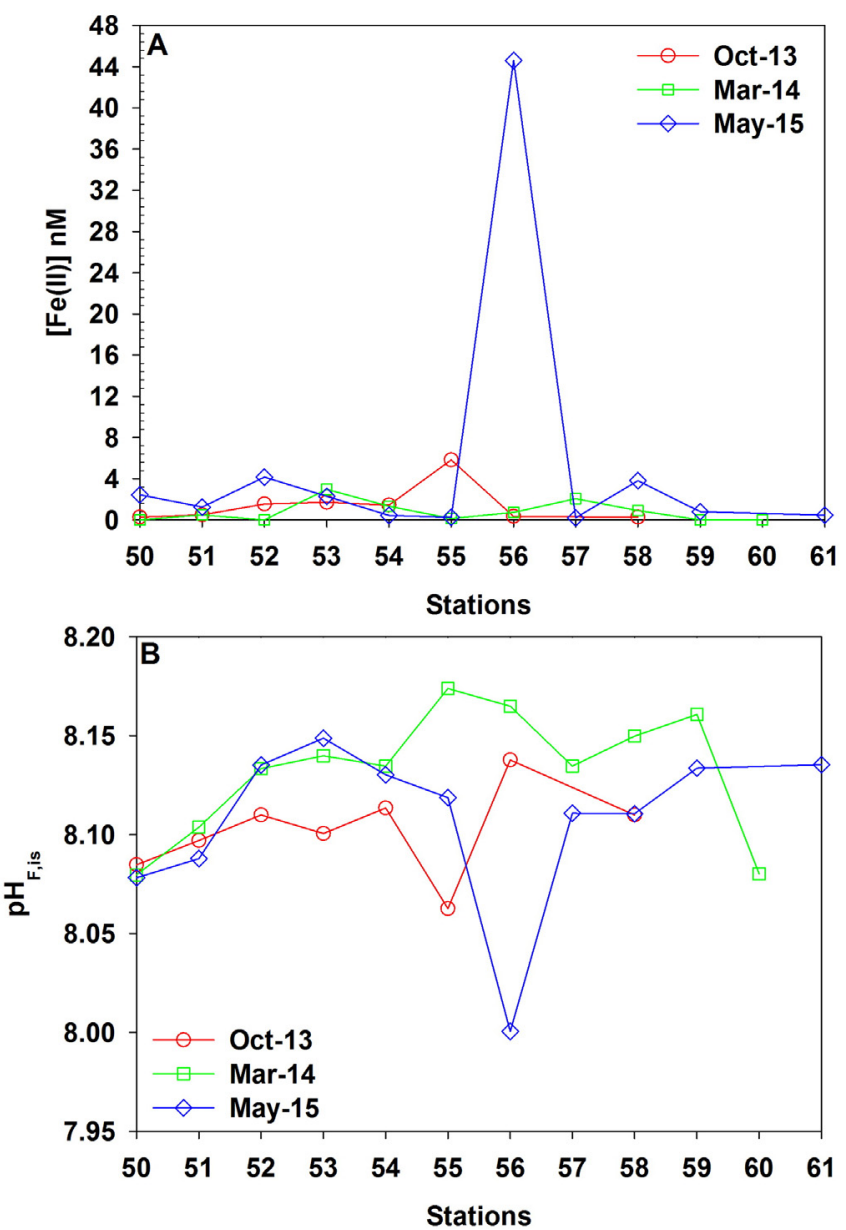

Fig. 6. A) TdFe(II) during October 2013, March 2014 and May 2015 at the bottom of the high-resolution section along the volcano transect. The main cone is located at station 56. $\mathrm{B}) \mathrm{pH}_{\mathrm{F}}$ is at the bottom of the high resolution section of the volcano transect.

depths in October 2013 and March 2014, respectively. There were also two low values at stations 52 and 58 , of 8.13 and 8.11, respectively.

The correlation coefficients between the changes in $\mathrm{pH}$ and those in TdFe(II) for each 2013, 2014 and 2015 cruise were 0.6, 0.5 and 0.6, respectively, indicating that the emitted fluids were rich in both carbonate species and TdFe(II). These coefficients also show that the correlation between changes in $\mathrm{pH}$ (due to the concentration of dissolved $\mathrm{CO}_{2}$ ) and changes in $\mathrm{TdFe}$ (II) may vary because of other factors that control $\mathrm{TdFe}(\mathrm{II})$. The changes in the ORP sensor values (dorp/dz) were also correlated with the anomalies observed for TdFe(II). However, no significant correlation was found between dorp/dz and TdFe(II), indicating that other reduced species were affecting the change in the ORP signal.

Bearing in mind that the half-life time of $\mathrm{Fe}(\mathrm{II})$ in seawater depends principally on the oxygen concentration, the $\mathrm{pH}$, and the composition of the medium, these waters offered a unique opportunity to study the kinetics of oxidation of Fe(II) in an area affected by hydrothermal conditions. For this purpose, several kinetic oxidation studies were carried out in order to gain insight on the behavior of $\mathrm{Fe}(\mathrm{II})$ in these conditions and the results were compared with data presented in the literature. Kinetics studies were done with two water samples: surface water with a salinity of 36.92 and deeper water with a salinity of 35.46. Each kinetic study was performed at different temperatures between 5 and $25^{\circ} \mathrm{C}$. Fig. 7 shows a linear dependence between the $\log k_{\text {app }}\left(\mathrm{M}^{-1} \mathrm{~min}^{-1}\right)$ and the temperature $\left(1000 / \mathrm{T} \mathrm{K}^{-1}\right)$ for both salinities. The energy of activation obtained was $35.5 \mathrm{~kJ} \mathrm{~mol}^{-1}$ and $72.1 \mathrm{~kJ} \mathrm{~mol}^{-1}$ at surface and deeper water, respectively. It is important to note that these results obtained at different $\mathrm{pH}$ values and salinities providing two different

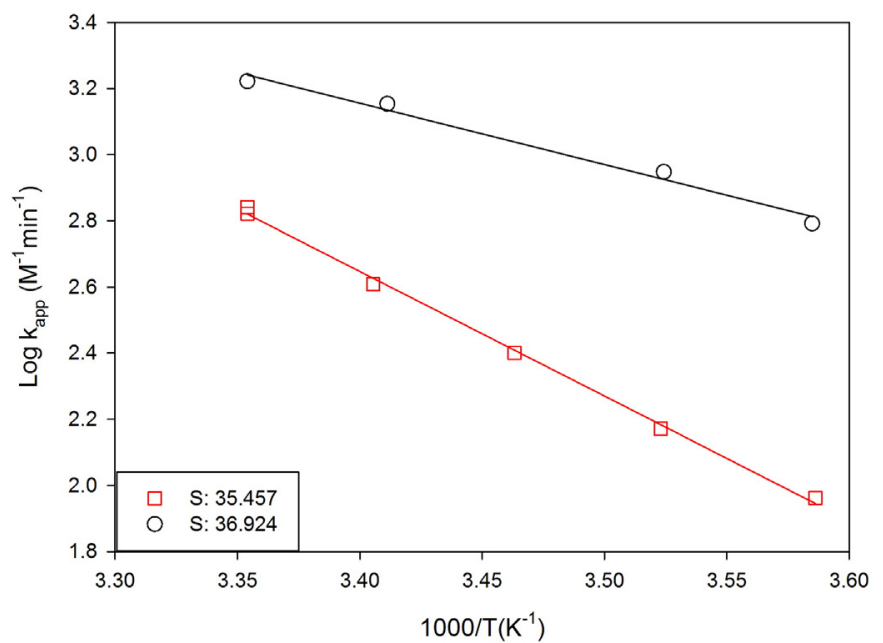

Fig. 7. Plot of $\log k_{\mathrm{app}}\left(\mathrm{M}^{-1} \mathrm{~min}^{-1}\right)$ and temperature $\left(1000 / \mathrm{KT}^{-1}\right)$ for the kinetic studies.

energies of activation, indicate that the oxidation mechanism is not the same at the surface and close to the emission area, with Fe(II) oxidation moreover affected by the $\mathrm{pH}_{\mathrm{F}, \text { is }}$ and salinity.

The surface waters $(5 \mathrm{~m})$ had $\mathrm{pH}_{\mathrm{F}}$ values of 8.13 and slightly higher and the deeper water $(343 \mathrm{~m})$ values of 7.75 and slightly higher at $25^{\circ} \mathrm{C}$. Values of $\mathrm{t}_{1 / 2}(\mathrm{~min}), \log k^{\prime}\left(\mathrm{min}^{-1}\right)$ and $\log k_{\mathrm{app}}\left(\mathrm{M}^{-1} \mathrm{~min}^{-1}\right)$ are shown as a function of temperature and $\mathrm{pH}_{\mathrm{F}}$ in Table 1 . The oxidation of $\mathrm{Fe}(\mathrm{II})$ follows a pseudo-first-order behavior. The Fe(II) oxidation kinetic in surface waters with higher $\mathrm{pH}_{\mathrm{F}}$ had faster oxidation rates than those at deeper waters, where the $\mathrm{pH}_{\mathrm{F}}$ was lower.

\section{Discussion}

The hydrothermal emissions around Tagoro submarine volcano off El Hierro island affect the $\mathrm{pH}$ of the surrounding waters as well as the $\mathrm{TdFe}(\mathrm{II})$ distribution in the water column. In the high resolution study along the volcanic edifice, positive anomalies in the vertical distribution of iron concentration were observed (Fig. 2A), located around $100 \mathrm{~m}$ depths, in station 55 in October 2013 and station 56 in March 2014 and May 2015. The iron concentration anomaly was also accompanied by an important anomaly in the $\mathrm{pH}_{\mathrm{F}, \text { is }}$ signal (Fig. 2B) (correlation coefficients of 0.6) at the same transect and at the same depth, with an opposite behavior. The low $\mathrm{pH}_{\mathrm{F} \text {,is }}$ values in the vertical distribution, along the full depth, are associated to $\mathrm{CO}_{2}$ emissions from hydrothermal vents located in the volcano area. The three carbonate system variables measured in these cruises, with high values of total dissolved inorganic carbon and alkalinity (data not shown) together with the low values of $\mathrm{pH}$, are completely consistent with the set of carbonic acidity constants of Mehrbach et al. (1973), refitted by Dickson and Millero (1987). These emissions also included important amounts of Fe(II) (Santana-Casiano et al., 2016, 2013). Low pH values help to maintain Fe(II) in solution for a longer period of time due to a decrease in its oxidation rate.

When a yo-yo sampling was carried out at station 55 (Fig. 3A and B), increases in the iron concentrations were also accompanied by a decrease in the $\mathrm{pH}_{\mathrm{F}, \text { is }}$ values for all the anomalies recorded. Both the decrease in the oxidation rate at low $\mathrm{pH}$ and the formation of complexed iron can help to maintain high concentrations of TdFe(II) in solution. The tow-yo sampling carried out across the volcano during the March 2014 cruise allowed us to more accurately determine the location of the sub-cones and emissions (Santana-Casiano et al., 2016). During the tow-yo sampling, important temporal anomalies were also detected in stations 56 and 61, indicating changes in the emitted fluid composition with time.

Although the $\mathrm{pH}_{\mathrm{F} \text {,is }}$ at the bottom of station 61, 61-61, was lower than that three and half hours before, 61-42, (Fig. 4B), the TdFe(II) concentration decreased. This behavior could be explained by considering 
Table 1

Measured and calculated Fe(II) oxidation rate constants at the different experimental conditions.

\begin{tabular}{|c|c|c|c|c|c|c|c|c|}
\hline Salinity & $\mathrm{t}\left({ }^{\circ} \mathrm{C}\right)$ & $\mathrm{pH}_{\mathrm{F}}$ & $t_{1 / 2}(\min )$ & $\log k^{\prime}\left(\min ^{-1}\right)$ & Standard error & $\log k_{\mathrm{app}}\left(\mathrm{M}^{-1} \min ^{-1}\right)$ & $\log k_{\mathrm{app}}\left(\mathrm{M}^{-1} \min ^{-1}\right)^{\mathrm{a}}$ & $\log k_{\mathrm{app}}\left(\mathrm{M}^{-1} \min ^{-1}\right)^{\mathrm{b}}$ \\
\hline \multirow[t]{6}{*}{35.457} & 25 & 7.75 & 4.69 & 0.831 & 0.01 & 2.841 & 2.741 & 2.650 \\
\hline & 25 & 7.75 & 4.91 & 0.850 & 0.01 & 2.821 & 2.741 & 2.650 \\
\hline & 20.5 & 7.77 & 7.41 & 1.029 & 0.01 & 2.609 & 3.012 & 2.882 \\
\hline & 15.6 & 7.82 & 10.93 & 1.198 & 0.01 & 2.400 & 2.331 & 2.221 \\
\hline & 10.7 & 7.84 & 16.78 & 1.384 & 0.01 & 2.171 & 2.078 & 1.962 \\
\hline & 5.7 & 7.94 & 24.32 & 1.545 & 0.01 & 1.962 & 1.908 & 1.776 \\
\hline \multirow[t]{4}{*}{36.924} & $25^{a}$ & 8.13 & 1.61 & 0.365 & 0.01 & 3.222 & 3.176 & 3.077 \\
\hline & $20^{\mathrm{b}}$ & 8.21 & 1.71 & 0.392 & 0.01 & 3.154 & 3.023 & 2.917 \\
\hline & 10.6 & 8.26 & 2.25 & 0.511 & 0.01 & 2.948 & 2.587 & 2.473 \\
\hline & 5.8 & 8.34 & 2.87 & 0.616 & 0.01 & 2.791 & 2.187 & 2.069 \\
\hline
\end{tabular}

$[\mathrm{Fe}(\mathrm{II})]_{0}=4.026 \mathrm{nM}$

The theoretical value of $\log K_{\mathrm{app}}\left(\mathrm{M}^{-1} \mathrm{~min}^{-1}\right)$ in seawater enriched with nutrients was calculated from (a) González et al. (2010) and (b) Samperio-Ramos et al. (2016).

a $[\mathrm{Fe}(\mathrm{II})]_{0}=16.106 \mathrm{nM}$.

b $[\mathrm{Fe}(\mathrm{II})]_{0}=9.664 \mathrm{nM}$.

changes in the emitted iron concentration and due to scavenging onto surfaces or the presence of less effective complexing substances. The high value obtained at the bottom depth of station 61-42 of $1278.9 \mathrm{nM}$ was, however, three orders of magnitude lower than the range of values determined in other hydrothermal vents, of 1-3 $\mathrm{mmol} \mathrm{L}^{-1}$ (de Baar and de Jong, 2001).

Moreover, values recorded for all cruises at the bottom across the volcano transect showed TdFe(II) concentrations (Fig. 6A) were a mirror image of those for $\mathrm{pH}_{\mathrm{F}, \text { is }}$ (Fig. 6B). The relationship between low $\mathrm{pH}_{\mathrm{F}, \text { is }}$ and high $\mathrm{TdFe}(\mathrm{II})$ concentrations indicated that emissions of hydrothermal fluids rich in acid and iron were active in the area, particularly in the proximities of station 55, during October 2013, and station 56, in March 2014 and May 2015, which were affecting the $\mathrm{pH}_{\mathrm{F} \text {,is }}$ and $\mathrm{TdFe}(\mathrm{II})$ profiles and the surrounding sea bottom values. However, other factors such as organic complexation and scavenging could also be important.

The Fe(II) oxidation kinetic studies carried out during May 2015 in the surrounding waters affected by the volcanic emissions provided important results. Both surface ( $\mathrm{S}=36.92)$ and deep $(341 \mathrm{~m}, \mathrm{~S}=35.46$ ) seawater followed a pseudo-first-order Fe(II) kinetic. For each value of salinity, oxidation became faster as the temperature increased. Moreover, the oxidation of $\mathrm{Fe}(\mathrm{II})$ was faster in surface waters with salinity of 36.92 and $\mathrm{pH}_{\mathrm{F} \text {,is }}$ over 8.12 than in deeper seawater (at $341 \mathrm{~m}$ ) with salinity of 35.46 and $\mathrm{pH}_{\mathrm{F} \text {,is }}$ over 7.75 at the same temperature.

In order to compare the $\log k_{\text {app }}$ with other previous data obtained at high nutrient concentrations, the experimental conditions of these studies $(\mathrm{pH}, \mathrm{T}$ and $\mathrm{S}$ ) were included in the empirical equation of González et al. (2010) and Samperio-Ramos et al. (2016), valid at high nutrient water concentration (Table 1). The $\log k_{\text {app }}\left(\mathrm{M}^{-1} \mathrm{~min}^{-1}\right)$ obtained at both salinities presented values very close to those obtained by González et al. (2010) and Samperio-Ramos et al. (2016). These values are faster than those expected in natural oligotrophic seawater with low concentrations of macronutrients (Santana-Casiano et al., 2005). In deeper water, with salinity $35.46,25^{\circ} \mathrm{C}$ and $\mathrm{pH}_{\mathrm{F}} 7.75, \log k_{\mathrm{app}}\left(\mathrm{M}^{-1} \mathrm{~min}^{-1}\right)$ was 2.841 , a similar value to the theoretical value of 2.741 reported in González et al. (2010) and 2.650 in Samperio-Ramos et al. (2016). At $5.7^{\circ} \mathrm{C}$ and $\mathrm{pH}_{\mathrm{F}}$ $7.94, \log k_{\mathrm{app}}\left(\mathrm{M}^{-1} \mathrm{~min}^{-1}\right)$ was 1.962 . This value is closer to the $1.908 \mathrm{re}-$ ported in González et al. (2010) than the 1.776 reported in SamperioRamos et al. (2016). However, at $20.5{ }^{\circ} \mathrm{C}$ and $\mathrm{pH}_{\mathrm{F}} 7.77$, the $\log k_{\mathrm{app}}$ $\left(\mathrm{M}^{-1} \mathrm{~min}^{-1}\right)$ was 2.609 , a value closer to the 2.882 reported in Samperio-Ramos et al. (2016) than the 3.012 value in González et al. (2010). In surface water, with salinity 36.92 , the rate was faster than in the deeper waters at the same temperature. This difference can be explained by considering the dependence of the Fe(II) oxidation rate on $\mathrm{pH}$ and on the different nutrient concentrations (data not shown) of the seawater samples and those in the model. $\log k_{\text {app }}$ presented values that were closer to those obtained in González et al. (2010) for $25^{\circ} \mathrm{C}$ and $20{ }^{\circ} \mathrm{C}$. However, at colder temperatures than $10.6{ }^{\circ} \mathrm{C}$ the $\log k_{\text {app }}$ presented higher values than the theoretical ones (when temperature increase $\mathrm{pH}_{\mathrm{F}}$ decreases due to the temperature effect and a gradual increase in $\log k_{\text {app }}$ values should be observed).

Kinetic studies carried out in the volcanic area showed Fe(II) oxidation rates were faster than those expected in natural oligotrophic seawater. In general, the values were more in line with those at high nutrient concentration. González et al. (2010) and Samperio-Ramos et al. (2016) demonstrated that the effect of high nutrient seawater, particularly related to higher silicate concentration, increases the $\mathrm{Fe}(\mathrm{II})$ oxidation rate. During the eruptive phase, important inputs of silicate in the area were measured (Santana-Casiano et al., 2013). The differences in $\log k_{\text {app }}$ between the three studies are probably due to different nutrient contents, metal interactions and the effect of nutrient content and type of organic matter. The emission of iron and nutrients (Santana-Casiano et al., 2013) also increases the rate of phytoplankton production (Fitzwater et al., 1996; Martin et al., 1994) which induces changes in organic iron complexation and $\mathrm{Fe}(\mathrm{II})$ oxidation rates favored at the low pH values in the area (Breitbarth et al., 2010). Iron-ligand complexes have been found in the seawater hydrothermal plumes rising above the vents (Bennett et al., 2008; Statham et al., 2005), which will affect metal concentration in hydrothermal fluids (Sander and Koschinsky, 2011) and change the reactivity of the Fe species, preventing precipitation of $\mathrm{Fe}$ and scavenging onto particulate phases (Bennett et al., 2008). Authors such as Breitbarth et al. (2010) observed that ocean acidification may lead to enhanced Fe-bioavailability due to an increased fraction of dFe and elevated $\mathrm{Fe}$ (II) concentrations in coastal systems. Moreover, seawater $\mathrm{pH}$ affects phytoplankton physiology (Fu et al., 2008), and thus indirect effects via phytoplankton exudates that complex iron may also alter the biological influence on iron solubility and cycling (Breitbarth et al., 2010). In our study, sub-maxima values of $\mathrm{Fe}(\mathrm{II})$ were always associated to the depth of the chlorophyll maximum, where organic excreted ligands could play the aforementioned roles. The anomalies observed at the bottom areas in $\mathrm{pH}_{\mathrm{F}, \text { is }}$ and $\mathrm{TdFe}(\mathrm{II})$ during the three cruises confirmed the emission of gases and reduced compounds in the volcano region, especially in the sub-cone located at station 55 in October 2013, at stations 56 and 61 in March 2014, and at station 56 in May 2015. The emission of hydrothermal fluids, rich in $\mathrm{CO}_{2}$ and in reduced iron forms (among other emitted metals which have not been considered), whose concentrations can change with time as was observed in the yo-yo studies, affects the surrounding volcanic area and contributes to an increase in the TdFe(II) that can enhance the biological activity as a result of this natural fertilization event.

\section{Conclusions}

The studies carried out during the three cruises in the area of the Tagoro submarine volcano off El Hierro island, showed important positive TdFe(II) anomalies, which were inversely correlated with negative 
anomalies in $\mathrm{pH}_{\mathrm{F}, \mathrm{is}}$. These studies allowed investigation of the temporal evolution of the total dissolved $\mathrm{Fe}(\mathrm{II})$ concentrations in the area and an analysis of the natural $\mathrm{Fe}(\mathrm{II})$ fertilization process.

It was observed that emissions of TdFe(II) continue in the area four years after cessation of the molten eruptive phase. The magnitude of $\mathrm{TdFe}(\mathrm{II})$ was not the same in all the sampling periods, with high variability over a short time scale, and was also inversely related to $\mathrm{pH}$. This may be due to changes in the mixing process along the shape of the volcano or changes in the amount of emitted fluids in the hydrothermal vents that mixed with the surrounded oxygenated waters. The kinetic studies in the volcanic area showed Fe(II) oxidation rates were higher than those expected in oligotrophic seawater. The increase in the $\mathrm{Fe}(\mathrm{II})$ oxidation rate can be explained by the higher amount of macronutrients, in particular silicates, in these waters.

This study has showed that the increased TdFe(II) concentrations due to the hydrothermal emissions may be acting as an important fertilization event in the seawater around the Tagoro submarine volcano near the island of El Hierro, providing optimal conditions for the regeneration of the area.

\section{Acknowledgements}

This work was supported by the Ministerio de Economía y Competitividad of the Spanish Government, through the ECOFEMA (CTM2010-19517), EACFe (CTM2014-52342-P) and VULCANO (CTM2012-36317) projects and by the Spanish Institute of Oceanography through the VULCANA (2015-2017) project. This work was completed while C.S-G was a Ph.D. student in the IOCAG Doctoral Program in Oceanography and Global Change.

Special thanks go to J. González-Santana and Stephen Henry Burns for their kind revision of the English and their comments.

\section{Appendix A. Supplementary data}

Supplementary data to this article can be found online at http://dx. doi.org/10.1016/j.marchem.2017.02.001.

\section{References}

Bennett, S.A., et al., 2008. The distribution and stabilisation of dissolved Fe in deep-sea hydrothermal plumes. Earth Planet. Sci. Lett. 270 (3), 157-167.

Benson, B.B., Krause, D., 1984. The concentration and isotopic fractionation of oxygen dissolved in freshwater and seawater in equilibrium with the atmosphere. Limnol. Oceanogr. 29 (3), 620-632.

Bowie, A.R., Achterberg, E.P., Mantoura, R.F.C., Worsfold, P.J., 1998. Determination of subnanomolar levels of iron in seawater using flow injection with chemiluminescence detection. Anal. Chim. Acta 361 (3), 189-200.

Brand, L.E., 1991. Minimum iron requirements of marine phytoplankton and the implications for the biogeochemical control of new production. Limnol. Oceanogr. 36 (8), 1756-1771.

Breitbarth, E., et al., 2010. Ocean acidification affects iron speciation during a coastal seawater mesocosm experiment. Biogeosciences 7 (3), 1065-1073.

Clayton, T.D., Byrne, R.H., 1993. Spectrophotometric seawater $\mathrm{pH}$ measurements: tota hydrogen ion concentration scale calibration of m-cresol purple and at-sea results. Deep-Sea Res. I Oceanogr. Res. Pap. 40 (10), 2115-2129.

de Baar, H.J.W., de Jong, J.T.M., 2001. Distributions, sources and sinks of iron in seawater In: Turner, D.R., Hunter, K.A. (Eds.), The Biogeochemistry of Iron in Sea Water. John Wiley \& Sons Ltd, p. 123.

Dickson, A., Millero, F.J., 1987. A comparison of the equilibrium constants for the dissociation of carbonic acid in seawater media. Deep Sea Res. Part A 34 (10), 1733-1743.

Field, M.P., Sherrell, R.M., 2000. Dissolved and particulate Fe in a hydrothermal plume at $9^{\circ} 45^{\prime} \mathrm{N}$, East Pacific rise:: slow Fe (II) oxidation kinetics in Pacific plumes. Geochim. Cosmochim. Acta 64 (4), 619-628.

Fitzwater, S.E., Coale, K.H., Gordon, R.M., Johnson, K.S., Ondrusek, M.E., 1996. Iron deficiency and phytoplankton growth in the equatorial Pacific. Deep-Sea Res. II Top. Stud. Oceanogr. 43 (4), 995-1015.

Fraile-Nuez, E., et al., 2012. The submarine volcano eruption at the island of El Hierro: physical-chemical perturbation and biological response. Sci. Rep. 2, 1-6.
Fu, F.-X., et al., 2008. Interactions between changing pCO2, N2 fixation, and Fe limitation in the marine unicellular cyanobacterium Crocosphaera. Limnol. Oceanogr. 53 (6), 2472-2484.

German, C., et al., 2015. Hydrothermal Fe cycling and deep ocean organic carbon scavenging: model-based evidence for significant POC supply to seafloor sediments. Earth Planet. Sci. Lett. 419, 143-153.

González, A.G., Santana-Casiano, J.M., Pérez, N., González-Dávila, M., 2010. Oxidation of Fe (II) in natural waters at high nutrient concentrations. Environ. Sci. Technol. 44 (21), 8095-8101.

González-Dávila, M., Santana-Casiano, J.M., Rueda, M.J., Llinás, O., González-Dávila, E.F., 2003. Seasonal and interannual variability of sea-surface carbon dioxide species at the European station for time series in the ocean at the Canary Islands (ESTOC) between 1996 and 2000. Glob. Biogeochem. Cycles 17 (3), 1-5.

González-Davila, M., Santana-Casiano, J.M., Millero, F.J., 2005. Oxidation of iron (II) nanomolar with $\mathrm{H}_{2} \mathrm{O}_{2}$ in seawater. Geochim. Cosmochim. Acta 69 (1), 83-93.

González-Dávila, M., Santana-Casiano, J.M., Millero, FJ., 2006. Competition between $\mathrm{O}_{2}$ and $\mathrm{H}_{2} \mathrm{O}_{2}$ in the oxidation of $\mathrm{Fe}$ (II) in natural waters. J. Solut. Chem. 35 (1), 95-111.

Hansard, S.P., Landing, W.M., 2009. Determination of iron (II) in acidified seawater samples by luminol chemiluminescence. Limnol. Oceanogr. Methods 7 (3), 222-234.

Hutchins, D.A., DiTullio, G.R., Burland, K.W., 1993. Iron and regenerated production: evidence for biological iron recycling in two marine environments. Limnol. Oceanogr. 38 (6), 1242-1255.

King, D., Farlow, R., 2000. Role of carbonate speciation on the oxidation of Fe (II) by $\mathrm{H}_{2} \mathrm{O}_{2}$. Mar. Chem. 70 (1), 201-209.

King, D.W., Lounsbury, H.A., Millero, F.J., 1995. Rates and mechanism of Fe (II) oxidation at nanomolar total iron concentrations. Environ. Sci. Technol. 29 (3), 818-824.

Kustka, A.B., Shaked, Y., Milligan, A.J., King, D.W., Morel, F.M., 2005. Extracellular production of superoxide by marine diatoms: contrasting effects on iron redox chemistry and bioavailability. Limnol. Oceanogr. 50 (4), 1172-1180.

Lewis, E., Wallace, D., Allison, L.J., 1998. Program Developed for $\mathrm{CO}_{2}$ System Calculations. Carbon Dioxide Information Analysis Center, Managed by Lockheed Martin Energy Research Corporation for the US Department of Energy Tennessee.

Liu, X., Millero, F.J., 2002. The solubility of iron in seawater. Mar. Chem. 77 (1), 43-54.

Luther, G.W., et al., 2001. Chemical speciation drives hydrothermal vent ecology. Nature 410 (6830), 813-816.

Mantas, V.M., Pereira, A., Morais, P.V., 2011. Plumes of discolored water of volcanic origin and possible implications for algal communities. The case of the home reef eruption of 2006 (Tonga, Southwest Pacific Ocean). Remote Sens. Environ. 115 (6), 1341-1352.

Martin, J.H., et al., 1994. Testing the iron hypothesis in ecosystems of the equatorial Pacific Ocean. Nature 371, 123.

Mehrbach, C.C.C.H., Hawley, J.E., Pytkowicx, R.M., 1973. Measurement of the apparent dissociation constants of carbonic acid in seawater at atmospheric pressure. Limnol. Oceanogr. 18 (6), 10.

Miller, W.L., King, D.W., Lin, J., Kester, D.R., 1995. Photochemical redox cycling of iron in coastal seawater. Mar. Chem. 50 (1), 63-77.

Millero, F.J., 1986. The pH of estuarine waters. Limnol. Oceanogr. 31 (4), 839-847.

Millero, F.J., Izaguirre, M., 1989. Effect of ionic strength and ionic interactions on the oxidation of Fe (II). J. Solut. Chem. 18 (6), 585-599.

Nishioka, J., Obata, H., Tsumune, D., 2013. Evidence of an extensive spread of hydrothermal dissolved iron in the Indian Ocean. Earth Planet. Sci. Lett. 361, 26-33.

Resing, J.A., et al., 2015. Basin-scale transport of hydrothermal dissolved metals across the South Pacific Ocean. Nature 523 (7559), 200-203.

Samperio-Ramos, G., Santana Casiano, J.M., González Dávila, M., 2016. Effect of ocean warming and acidification on the Fe(II) oxidation rate in oligotrophic and eutrophic natural waters. Biogeochemistry 128 (1), 19-34

Sander, S.G., Koschinsky, A., 2011. Metal flux from hydrothermal vents increased by organic complexation. Nat. Geosci. 4 (3), 145-150.

Santana-Casiano, J., González-Dávila, M., 2011. pH decrease and effects on the chemistry of seawater. In: Duarte, P., Santana-Casiano, J.M. (Eds.), Oceans and the Atmospheric Carbon Content. Springer Netherlands, pp. 95-114.

Santana-Casiano, J.M., González-Dávila, M., Millero, F.J., 2004. The oxidation of Fe (II) in $\mathrm{NaCl}-\mathrm{HCO}_{3}^{-}$and seawater solutions in the presence of phthalate and salicylate ions: a kinetic model. Mar. Chem. 85 (1), 27-40.

Santana-Casiano, J.M., González-Dávila, M., Millero, F.J., 2005. Oxidation of nanomolar levels of Fe (II) with oxygen in natural waters. Environ. Sci. Technology 39 (7), 2073-2079.

Santana-Casiano, J.M., et al., 2013. The natural ocean acidification and fertilization event caused by the submarine eruption of El Hierro. Sci. Rep. 3, 1-8.

Santana-Casiano, J., et al., 2016. Significant discharge of $\mathrm{CO}_{2}$ from hydrothermalism associated with the submarine volcano of El Hierro Island. Sci. Rep. 6.

Shi, D., Xu, Y., Hopkinson, B.M., Morel, F.M., 2010. Effect of ocean acidification on iron availability to marine phytoplankton. Science 327 (5966), 676-679.

Statham, P., German, C., Connelly, D., 2005. Iron (II) distribution and oxidation kinetics in hydrothermal plumes at the Kairei and Edmond vent sites, Indian Ocean. Earth Planet. Sci. Lett. 236 (3), 588-596.

Tagliabue, A., et al., 2010. Hydrothermal contribution to the oceanic dissolved iron inventory. Nat. Geosci. 3 (4), 252-256.

Yücel, M., Gartman, A., Chan, C.S., Luther, G.W., 2011. Hydrothermal vents as a kinetically stable source of iron-sulphide-bearing nanoparticles to the ocean. Nat. Geosci. 4 (6), 367-371. 